\title{
EFFECT OF HEAT TREATMENT ON THE GRAIN SIZE, MICROHARDNESS AND CORROSION BEHAVIOR OF THE COLD-WORKING TOOL STEELS AISI D2 AND AISI O1
}

\author{
VPLIV TOPLOTNE OBDELAVE NA VELIKOST KRISTALNIH ZRN, \\ MIKROTRDOTO IN KOROZIJSKE LASTNOSTI DVEH VRST \\ (AISI D2 IN AISI O1) HLADNO DEFORMIRANIH ORODNIH JEKEL
}

\author{
Safwan Al-Qawabah ${ }^{1 *}$, Ahmad Mostafa', Aiman Al-Rawajfeh ${ }^{3}$, \\ Ubeidulla Al-Qawabeha ${ }^{1}$ \\ ${ }^{1}$ Mechanical Engineering Department, Al-Zaytoonah University of Jordan, Amman, Jordan \\ ${ }^{2}$ Mechanical Engineering Department, Tafila Technical University, Tafila 66110, Jordan \\ ${ }^{3}$ Chemical Engineering Department, Tafila Technical University, Tafila 66110, Jordan
}

Prejem rokopisa - received: 2020-03-23; sprejem za objavo - accepted for publication: 2020-07-15

doi:10.17222/mit.2020.035

\begin{abstract}
The current work focuses on the effect of heat treatment on the grain size, microhardness and corrosion behavior of AISI D2 and O1 tools steels. Samples of the investigated steels were subjected to different heat treatment (quenching and tempering) regimes. The hardening temperatures for AISI D2 steel were in the range $850-1000{ }^{\circ} \mathrm{C}$ with $50{ }^{\circ} \mathrm{C}$ step and in the range $780-870{ }^{\circ} \mathrm{C}$ with $30{ }^{\circ} \mathrm{C}$ step for AISI O1 steel. The tempering temperatures were fixed for AISI D2 and O1 specimens at $550^{\circ} \mathrm{C}$ and $450{ }^{\circ} \mathrm{C}$, respectively, to investigate the influence of the hardening temperature only. The results show that the grain size of heat-treated steels decreased by increasing the hardening temperature and thus the microhardness number increased due to the dense grain-boundary areas in the fine structures. The corrosion behaviors of the steel specimens were assessed in $0.1-\mathrm{M} \mathrm{HCl}$ solution using a potentiostatic polarization technique. The immersed AISI D2 specimens showed better corrosion resistance than that of AISI O1 due to the presence of high alloying elements, which may help in forming a protective layer against corrosion. The corrosion rates of the coarse-grained structures were less than that of the fine-grained structures, because the finer the grains, the greater the anodic areas, which leads to higher corrosion rates.
\end{abstract}

Keywords: microhardness, heat treatment, grain size, corrosion resistance

V prispevku so se avtorji osredotočili na določitev vpliva toplotne obdelave dveh vrst orodnih jekel (AISI D2 in O1) na njuno velikost kristalnih zrn, mikro trdoto in odpornost proti koroziji. Vzorce jekel so toplotno obdelali pri različnih režimih kaljenja in popuščanja. Za jeklo AISI D2 so za temperaturno območje austenitizacije izbrali temperature med 850 in $1000{ }^{\circ} \mathrm{C}$ v korakih po $50{ }^{\circ} \mathrm{C}$, medtem ko so za jeklo AISI O1 izbrali območje med $780-870{ }^{\circ} \mathrm{C} \mathrm{v}$ korakih po $30{ }^{\circ} \mathrm{C}$. Za ugotavljanja vpliva utrjevanja obeh vrst jekel so izbrali dve temperaturi popuščanja in sicer $550{ }^{\circ} \mathrm{C}$ in $450{ }^{\circ} \mathrm{C}$. Rezultati raziskav so pokazali, da se velikost zrn toplotno obdelanih jekel zmanjšuje z naraščajočo temperaturo austenitizacije in zato narašča tudi mikrotrdota zaradi večje gostote kristalnih mej v drobnozrnati mikrostrukturi jekel. Korozijsko obnašanje vzorcev jekel so analizirali v $0,1 \mathrm{M}$ raztopini $\mathrm{HCl}$ s potenciostatično polarizacijo. V raztopino potopljeni vzorci jekla AISI D2 so imeli boljšo odpornost proti koroziji kot vzorci jekla AISI O1 zaradi večje vsebnosti zlitinskih elementov, ki pomagajo pri tvorbi zaščitne plasti. Hitrost korozije grobo zrnatih mikrostruktur jekel je bila manjša kot tistih s fino zrnato mikrostrukturo, ker imajo le te večja anodna področja, kar vodi do višjih korozijskih hitrosti.

Ključne besede: mikrotrdota, toplotna obdelava, velikost zrn, odpornost proti koroziji

\section{INTRODUCTION}

The grain size of structural tool steels significantly affects their mechanical properties by the well-known Hall-Petch relationship. ${ }^{1,2}$ without modification of the chemistry of the base alloy. ${ }^{3}$ Generally, the mechanical performance deteriorates in large-grained structures, because of the dislocation motion that creates the potential for extensive plastic flow. ${ }^{4}$ However, the large-grained structures are accompanied by a low volume of grain boundaries and are expected to be less active in corrosive environments for pure iron. ${ }^{5}$ High corrosion resistance results in the long service life of tool-steel parts. The

*Corresponding author's e-mail:

safwan.q@zuj.edu.jo (Safwan Al-Qawabah)
AISI D2 and O1 steels are designated as cold-work tool steels and are used in making tools and dies for blanking, punching, forming and other operations requiring high compressive strength and excellent wear resistance. ${ }^{6}$ Despite the good mechanical properties of D2 and O1 steels, the lifetime of parts fabricated from these steels is negatively affected by the increase in the severity of working conditions and corrosive operating environments. ${ }^{7}$ Such steels are generally used in different industries where they come into contact with mineral acids such as $\mathrm{HCl}$, which are used for the cleaning and pickling of metal surfaces. ${ }^{8}$ Therefore, the need for improving the corrosion performance has increased rapidly in recent years, opening up a considerable number of opportunities for new technologies to resolve such a problem. ${ }^{9}$ There are some drawbacks associated with the ef- 
Table 1: Chemical composition of D2 and O1 alloy steels $(w / \%)$

\begin{tabular}{|c|c|c|c|c|c|c|c|c|}
\hline AISI & C & Si & Mn & Cr & Mo & V & W & Fe \\
\hline D2 & 1.55 & 0.3 & 0.4 & 11.8 & 0.8 & 0.8 & - \\
\hline O1 & 0.95 & - & 1.1 & 0.6 & - & Bal. & 0.1 & 0.6 \\
\hline
\end{tabular}

fects of grain size on corrosion resistance, which arise largely from the difficulty in isolating grain size effects from other microstructural changes caused by grain size control processes. ${ }^{3}$ To the authors' knowledge, very limited information on the effects of grain size on the corrosion behavior of AISI D2 tool steel can be found in the literature, whereas no information related to AISI O1 tool steel can be found. For instance, Yasavol and Jafari. ${ }^{10}$ observed an improved corrosion resistance of a friction-stir-welded AISI D2 steel due to the high volume fraction of low-angle grain boundaries in the ultrafine-grain layers. This work aims at studying the effect of different grain sizes, obtained by systematic hardening and tempering thermal treatment schemes, on the corrosion behavior of AISI D2 and O1 tool steels. The heat-treatment and corrosion-rate results can be of high importance for the use of D2 and O1 steels in industry under corrosive environment. The controlled grain size, obtained by an optimized heat treatment procedure, could offer a low-cost corrosion inhibitor for the investigated steel grades.

\section{EXPERIMENTAL PART}

An equivalent to AISI D2 and O1 cold-working tool steel discs of $20 \mathrm{~mm}$ diameter, provided from ASSAB Steels with the chemical composition given in Table $\mathbf{1}$ (in $w / \%$ ), were subjected to several heat treatment schemes. Schematic illustrations of the thermal treatment cycles are shown in Figure 1. The treated specimens
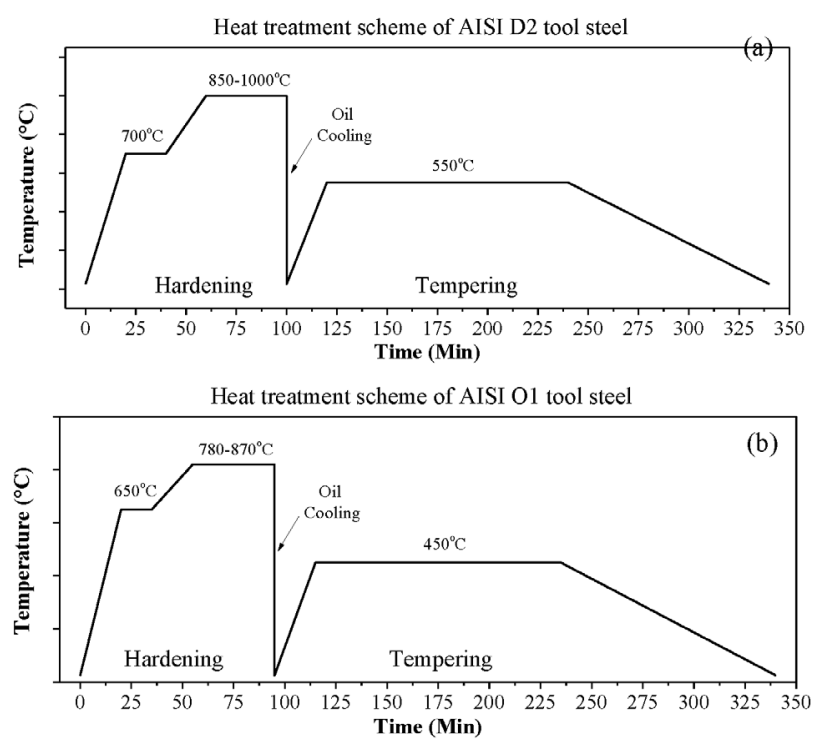

Figure 1: Heat-treatment schemes of: a) AISI D2 tool steel and b) AISI O1 tool steel were prepared for metallographic investigation by mounting them in hot-setting epoxy mounts, polished using gradual numbers of sandpapers from 200 to 2000 grit size, and etched with Nital solution ( $3 \% \mathrm{v} / \mathrm{v}$ nitric acid in methanol) for $15 \mathrm{~s}$ to $30 \mathrm{~s}$.

The etching chemicals were provided by Fisher Scientific Company. The microstructure of the treated specimens was examined using a Nikon Epiphot 200 metallurgical optical microscope (OM) at $200 \times$ magnification. Microhardness of the treated specimens was measured using a Highwood HWDM-3 (TTS Unlimited Inc., Japan) Vickers micro-indentation instrument under $500 \mathrm{~g}$ of load. An average of three values was taken for each measurement to ensure data accuracy. The grain size measurements were carried out according to ASTM E112-12.11 (Standard Test Methods for Determining Average Grain Size) using the intercept method. Interested readers could refer to the standard document for detailed test information.

Corrosion behavior was assessed in $0.1-\mathrm{M} \mathrm{HCl}$ solution (Fisher Scientific Company) using a potentiostatic polarization device according to ASTM G31-72.12 standard procedure. A radiometer analytical model PGZ 100 Potentiostat/ Galvanostat with VoltaLab software was used to analyze the corrosion results. A standard calomel electrode was used as a reference and a platinum wire as the counter-electrode. The treated specimens were used as the working electrode. A scan rate of $1 \mathrm{mV} / \mathrm{s}$ starting from $150 \mathrm{mV}$ below to $50 \mathrm{mV}$ above the testing cell instant potential was operated to run the experiment. The corrosion potential $\left(E_{\text {corr }}\right)$ and corrosion current density $\left(I_{\text {corr }}\right)$ of each specimen were determined using the Tafel plot method. All electrochemical experiments were performed at $22 \pm 1{ }^{\circ} \mathrm{C}$ in $150 \mathrm{~mL}$ of solution.

\section{RESULTS AND DISCUSSION}

\subsection{Effect of hardening temperature on the grain size}

The effect of hardening temperature on the grain size was studied and the results are presented in this section. Figure 2 shows the microstructure of quenched and tempered steels, taking into account the lowest and highest temperatures for steel samples according to the information in Figure 1. Similar microstructures for both tool steels were reported by Roberts et al. ${ }^{13}$ It could be seen that the grain sizes of both AISI D2 and AISI O1 steels decreased by increasing the hardening temperature. For instance, the grain size of AISI D2 steel was reduced gradually from $22.7 \mu \mathrm{m}$ to $15.8 \mu \mathrm{m}$ with a $50{ }^{\circ} \mathrm{C}$ incremental increase in the hardening temperature. On the other hand, the grain size of AISI O1 steel was reduced 

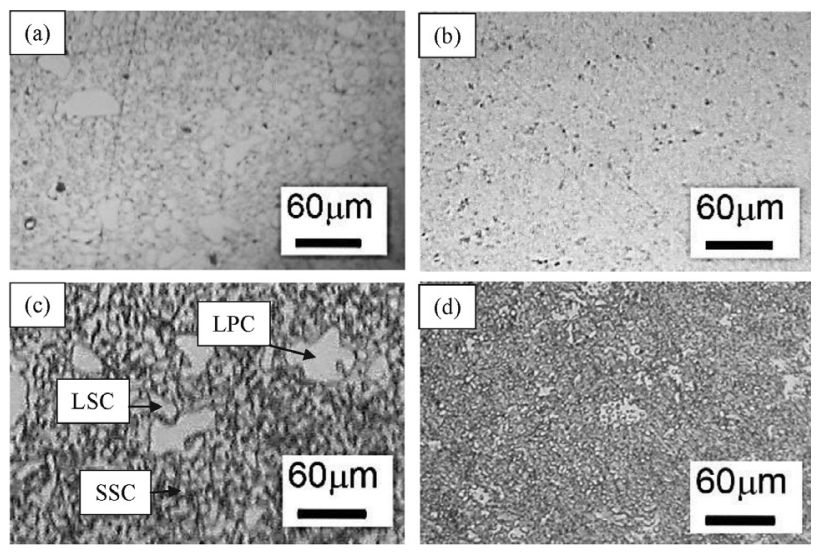

Figure 2: Optical micrographs for heat-treated and tempered steels: a) and b) for AISI D2 steel treated at 850 and $1000^{\circ} \mathrm{C}$, respectively, c) and d) for AISI O1 steel treated at $780{ }^{\circ} \mathrm{C}$ and $870{ }^{\circ} \mathrm{C}$, respectively

from $56.3 \mu \mathrm{m}$ to $32.6 \mu \mathrm{m}$ with a $30{ }^{\circ} \mathrm{C}$ incremental temperature increase from 780 to $870{ }^{\circ} \mathrm{C}$, respectively. The calculated average grain sizes for AISI D2 and O1 steels in the investigated temperature ranges are presented by bar charts in Figure 3. The bar charts show a typical relationship between the hardening temperature and the grain size, i.e., the grain size decreases by increasing the hardening temperature. This relationship is related to the critical temperature of the steels, which is the so-called austenitizing temperature.

The austenitizing temperature is the critical temperature necessary for the transformation in steel alloys to take place after a long enough time. The fully austenitized alloy can undergo a complete transformation upon quenching to form the uniform hard martensite structure shown in Figures $\mathbf{2 b}$ and $\mathbf{2 d}$. On the other hand, when alloys are heated below this critical temperature, an incomplete transformation may occur, which results in a non-uniform structure ${ }^{14}$ as could be seen in Figures 2a and 2c. For the investigated AISI D2 and O1 steels, the austenitizing temperatures are $1000^{\circ} \mathrm{C}$ and $820{ }^{\circ} \mathrm{C}$, respectively

\subsection{Grain size vs. microhardness relationship}

The grain size is inversely proportional to the microhardness number, as shown in Figure 4. The increase in microhardness could be due to the high grain-boundary
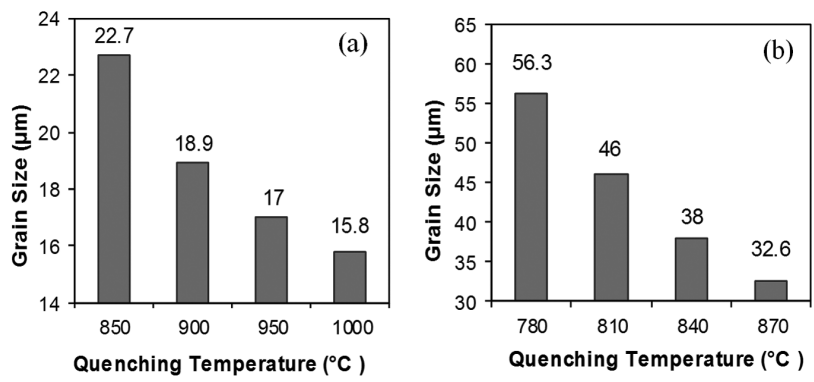

Figure 3: Effect of hardening temperature on grain sizes of: a) AISI D2 and b) AISI O1 steel specimens density in the fine-grained structure. ${ }^{15,16}$ The effect of grain size on the material strength and hardness is known as the grain-boundary strengthening mechanism 1 and is defined by the Hall-Pitch 2 relationships as:

$$
\begin{aligned}
& \sigma_{\mathrm{y}}=\sigma_{0}+\left(k_{y} * d^{-0.5}\right) \\
& H=H_{0}+\left(k_{\mathrm{H}} * d^{-0.5}\right)
\end{aligned}
$$

where $\sigma_{y}$ is the yield stress, $d$ is the average grain diameter, $\sigma_{o}, k_{y}, H_{\mathrm{o}}$ and $k_{\mathrm{H}}$ are material constants and $H$ is the hardness number. According to these equations, as the grain size increases, yield strength $\sigma_{y}$ decreases, and hardness decreases.

The microhardness could also be increased due to the formation of the hard martensite structure. The finer structure is known to have a complete martensitic transformation. Both AISI D2 and O1 tool steels contain other alloying elements than carbon, such as manganese $(\mathrm{Mn})$, chromium $(\mathrm{Cr})$, and vanadium $(\mathrm{V})$ as demonstrated in Table 1, which are known as precipitate-forming elements. ${ }^{17}$ Therefore, a secondary hardening effect can occur due to the segregation of the alloying elements precipitates. ${ }^{18}$ Table 2 summarizes the grain size and microhardness of the AISI D2 and O1 tool steel as functions of hardening temperature.

It can be concluded from Table 2 that the microhardness is directly proportional to the hardening temperature and inversely proportional to the grain size. In other words, the highest microhardness was recorded for the finer grain structure, which obtained at the highest hardening temperature.

\subsection{Corrosion properties}

The influences of grain sizes on the corrosion behavior of both AISI D2 and O1 tool steels were investigated using potentiodynamic polarization curves. The typical potentiodynamic polarization curves for the AISI D2 and O1 steels, of different grain sizes, immersed in 0.1-M $\mathrm{HCl}$ solution are presented in Figures $\mathbf{5} \mathbf{a}$ and $\mathbf{5 b}$, respectively. The corrosion rate in $\mathrm{mm} /$ year was calculated using Equation (1). ${ }^{19}$

Corrosion rate $(\mathrm{mm} /$ year $)=3.28 \times I_{\text {corr }} \times(M / n \rho)$

where $M$ is the atomic weight of Fe $(55.85 \mathrm{~g}), n$ is the number of electrons transferred in the corrosion reaction $(n=2)$ and $\rho$ is the density $\left(7.78 \mathrm{~g} / \mathrm{cm}^{3}\right.$ for AISI D2 and
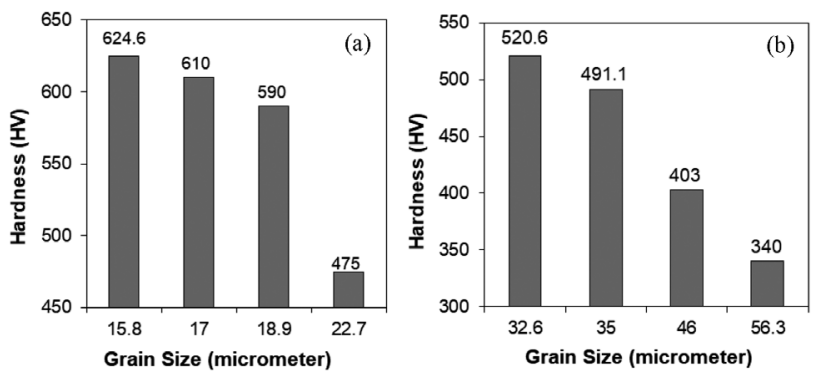

Figure 4: Effect of grain size on the microhardness of: a) AISI D2 and b) AISI O1 steel specimens 
S. AL-QAWABAH et al: EFFECT OF HEAT TREATMENT ON THE GRAIN SIZE, MICROHARDNESS ...

Table 2: Relationships between grain size and microhardness as functions of hardening temperatures for AISI D2 and O1 tools steels

\begin{tabular}{|c|c|c|c|c|c|}
\hline \multirow[b]{2}{*}{ Specimen No. } & \multirow[b]{2}{*}{ AISI } & \multicolumn{2}{|c|}{ Heat treatment regime } & \multirow[b]{2}{*}{$\begin{array}{l}\text { Average Grain Size } \\
\qquad(\mu \mathrm{m})\end{array}$} & \multirow[b]{2}{*}{$\begin{array}{c}\text { Average Microhard- } \\
\text { ness (HV) }\end{array}$} \\
\hline & & $\begin{array}{l}\text { Hardening Tempera- } \\
\text { ture }\left({ }^{\circ} \mathrm{C}\right)\end{array}$ & $\begin{array}{c}\text { Tempering Tempera- } \\
\text { ture }\left({ }^{\circ} \mathrm{C}\right)\end{array}$ & & \\
\hline 1 & \multirow{4}{*}{ D2 } & 850 & 540 & 22.7 & 475.0 \\
\hline 2 & & 900 & 540 & 18.9 & 590.0 \\
\hline 3 & & 950 & 540 & 17.0 & 610.0 \\
\hline 4 & & 1000 & 540 & 15.8 & 624.6 \\
\hline 1 & \multirow{4}{*}{$\mathrm{O} 1$} & 780 & 450 & 56.3 & 340.0 \\
\hline 2 & & 810 & 450 & 46.0 & 403.0 \\
\hline 3 & & 840 & 450 & 38.0 & 491.1 \\
\hline 4 & & 870 & 450 & 32.6 & 520.6 \\
\hline
\end{tabular}
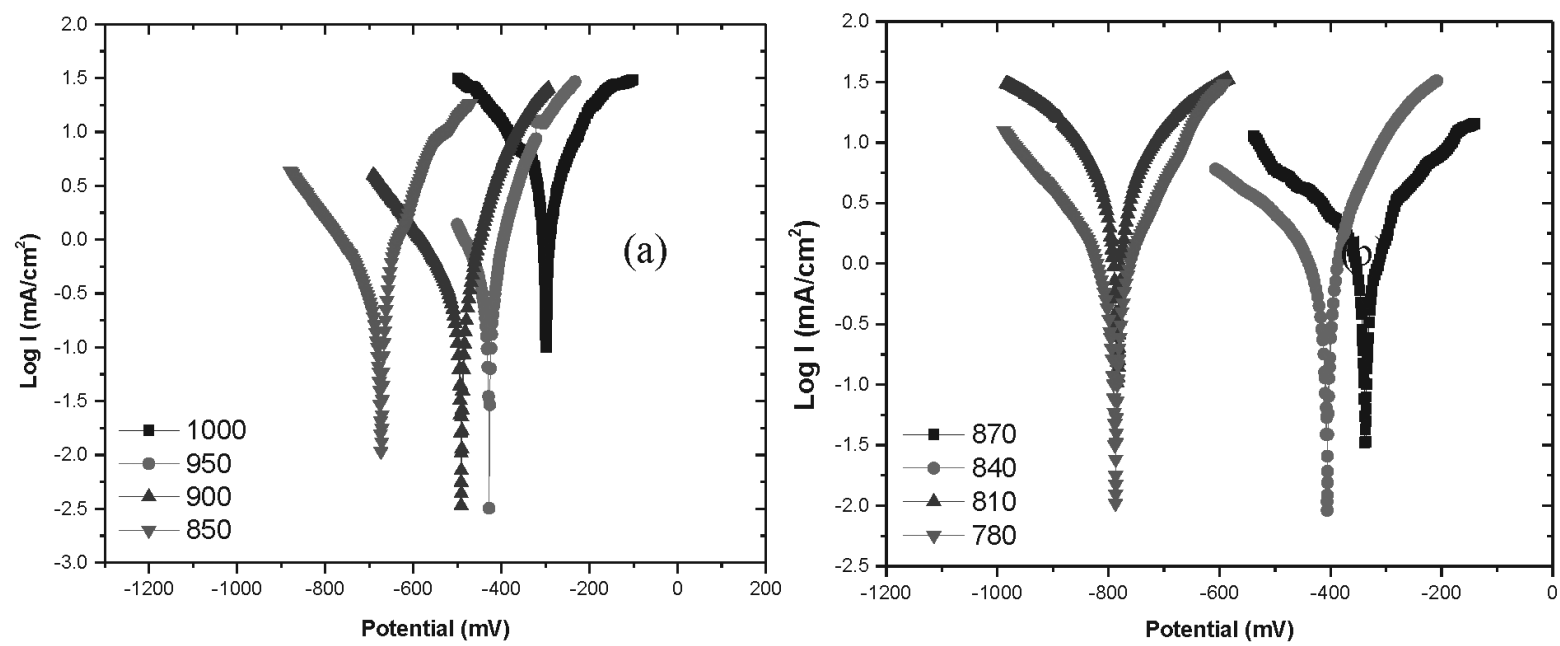

Figure 5: Potentiodynamic polarization curves of: a) AISI D2 and b) AISI O1 tool steels in 0.1-M HCl solution

$7.85 \mathrm{~g} / \mathrm{cm}^{3}$ for AISI O1). All $I_{\text {corr }}$ values were obtained by extrapolating the Tafel regions. ${ }^{20}$ The Tafel slopes for the anodic and cathodic reactions can be obtained from the linear regions of the polarization curve. Once these slopes have been established, the anodic and cathodic regions can be extrapolated back to the point where the anodic and cathodic reaction rates are equivalent. The current density at that point is the corrosion current density $\left(I_{\text {corr }}\right)$ and the potential at which it falls is the corrosion potential $\left(E_{\text {corr }}\right) .^{21}$

Figures $6 \mathbf{a}$ and $\mathbf{6 b}$ show the corrosion current density $\left(I_{\text {corr }}\right)$ and corrosion potential $\left(E_{\text {corr }}\right)$ of AISI D2 and O1 steels, respectively, which were obtained by the Tafel extrapolation method. The electrochemical parameters, $E_{\text {corr }}, I_{\text {corr, }}$ and corrosion rate (in $\mathrm{mm} / \mathrm{Y}$ ) for both steels, calculated from Figure 5, are summarized in Table 3. The corrosion potential for AISI D2 in Figure 5a was increasing with the increase in the hardening temperature. The small variation in the corrosion rate of AISI D2 treated at $900{ }^{\circ} \mathrm{C}$ could be due to that the insignificant difference in the grain size values with the samples treated at $950{ }^{\circ} \mathrm{C}$. Similarly, the corrosion potential was increasing with temperature increase for AISI O1 steel samples as well. In other words, the corrosion potential of the fine-grained structures is higher than that of the coarse-grained structures. The increased corrosion poten-
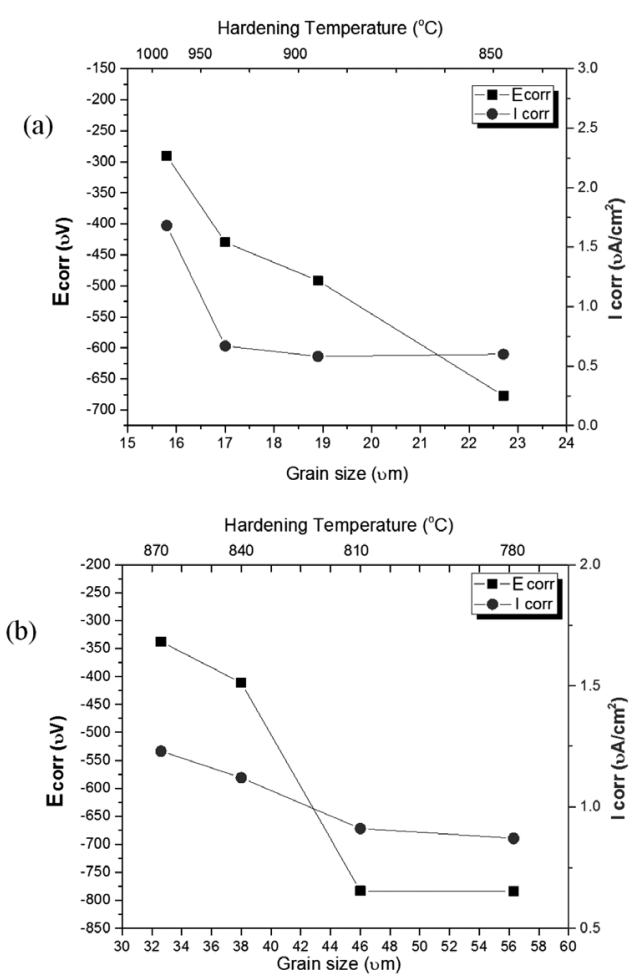

Figure 6: Variation of experimental corrosion potential and corrosion current density with grain size and temperature for: a) AISI D2 and b) AISI $\mathrm{O} 1$ steels in $0.1-\mathrm{M} \mathrm{HCl}$ solution 
tial suggests that fine-grained samples are more susceptible to corrosion. It can also be seen from Figure $\mathbf{5}$ and Figure 6 that the $I_{\text {corr }}$ values increase when the grain size decreases. The lower current density values indicate that the corrosion rate (in $\mathrm{mm} / \mathrm{Y}$ ) is decreasing. This can be attributed to the fact that making the grains finer renders greater anodic areas than in the coarse grains and thus leads to higher corrosion rates. ${ }^{22}$

Corrosion rates of $(7.06,6.82,7.88$, and 19.77) $\mathrm{mm} /$ year were obtained for AISI D2 samples treated at $(850,900,950$, and 1000$){ }^{\circ} \mathrm{C}$, respectively. Whereas corrosion rates of $(10.15,10.50,13.06$, and 14.35$) \mathrm{mm} /$ year were obtained for AISI O1 samples treated at (780, 810, 840 , and 870) ${ }^{\circ} \mathrm{C}$, respectively. It can be concluded that the computed corrosion rates were increasing with an increase in the hardening temperature at which the grain size was decreasing. This increase in the corrosion rate implies that the corrosion resistance decreases when the grain size decreases. Grain boundaries could be anodic initiation sites for pit formation. However, since fine microstructures have more initiation sites, more pits would grow critical due to the presence of compensating cathode area. ${ }^{23}$

Table 3: Electrochemical parameters for the AISI D2 and O1 specimens in $0.1 \mathrm{M} \mathrm{HCl}$ solution

\begin{tabular}{|c|c|c|c|}
\hline $\mathrm{D} 2$ & $\begin{array}{c}E_{\text {corr }} \\
(\mathrm{mV})\end{array}$ & $\begin{array}{c}I_{\text {corr }} \\
\left(\mathrm{mA} / \mathrm{cm}^{2}\right)\end{array}$ & $\begin{array}{c}\text { Corrosion rate } \\
(\mathrm{mm} / \mathrm{Y})\end{array}$ \\
\hline 850 & -679.8 & 0.60 & 7.06 \\
\hline 900 & -491.8 & 0.58 & 6.82 \\
\hline 950 & -429.5 & 0.67 & 7.88 \\
\hline 1000 & -290.4 & 1.68 & 19.77 \\
\hline $\mathrm{O} 1$ & $\begin{array}{c}E_{\text {corr }} \\
(\mathrm{mV})\end{array}$ & $\begin{array}{c}I_{\text {corr }} \\
\left(\mathrm{mA} / \mathrm{cm}^{2}\right)\end{array}$ & $\begin{array}{c}\text { Corrosion rate } \\
(\mathrm{mm} / \mathrm{Y})\end{array}$ \\
\hline 780 & -784.2 & 0.87 & 10.15 \\
\hline 810 & -783.1 & 0.91 & 10.50 \\
\hline 840 & -411.3 & 1.12 & 13.06 \\
\hline 870 & -342.3 & 1.23 & 14.35 \\
\hline
\end{tabular}

It is noted from Table 3 that the AISI O1 steel is more susceptible to corrosion in the $\mathrm{HCl}$ solution than the AISI D2 steel. The improved corrosion resistance of AISI D2 steel could be due to the presence of chromium (Cr), molybdenum (Mo), and vanadium (V) alloying elements, which sacrifice corrosion for the iron. The corrosion of these alloying elements forms a protective layer of reaction products on the martensite surface. ${ }^{23}$ The same effect was reported by Revie et al. ${ }^{24}$ who stated that the corrosion potential increases to the reference state when more alloying elements are present due to the reaction-product layer formation on the alloy's surface during corrosion. The corroded surfaces for the AISI D2 and O1 steels treated at different temperatures are shown in Figure 7.

It can be concluded from the surface examination that the corrosion has taken place in all samples. However,
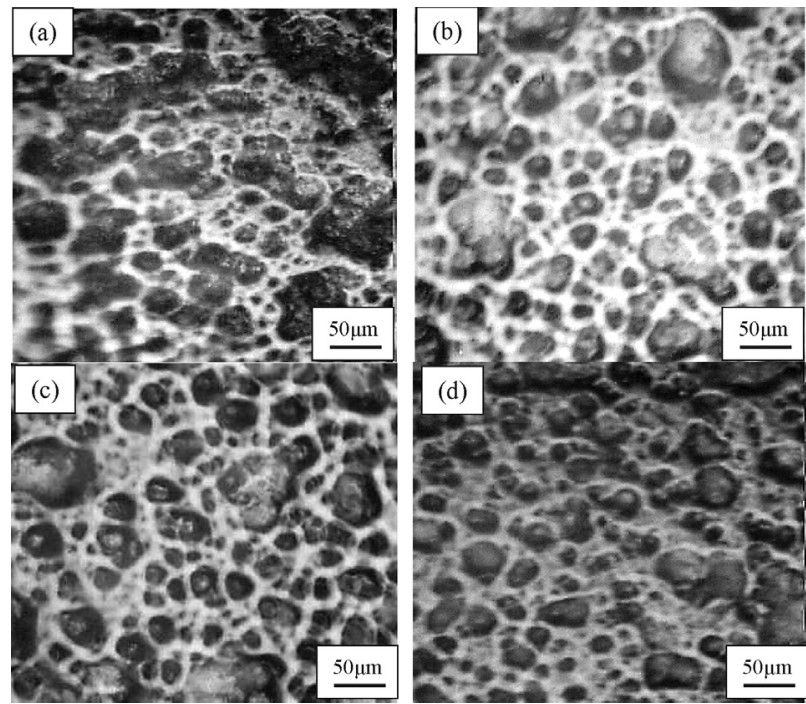

Figure 7: Micrographs of oil-quenched specimens for: a) and b) AISI D2 treated at $850{ }^{\circ} \mathrm{C}$ and $1000{ }^{\circ} \mathrm{C}$, respectively, c) and d) for AISI O1 treated at $780{ }^{\circ} \mathrm{C}$ and $870{ }^{\circ} \mathrm{C}$, respectively

the corrosion effect was very obvious in the AISI O1 specimens. Furthermore, the depth and size of the pits in the fine-grained material, in Figure $\mathbf{7 b}$ and $\mathbf{7 d}$, were found to be larger than those in the coarse-grained samples in Figure 7a and 7c due to the presence of the compensating cathode area in the dense gain-boundary areas.

\section{CONCLUSIONS}

The current study focused on the effect of the heat-treatment regimes on the grain size, microhardness, and corrosion behavior of AISI D2 and O1 tool steels. A typical relationship between hardening temperature and both grain size and microhardness number was obtained. The fine-grained structures were obtained at high hardening temperatures, because of complete martensite transformation. Whereas at lower temperatures, an incomplete transformation took place and coarse-grained structures were obtained. The microhardness number increased for the fine-grained structures due to the dense grain-boundary areas and the presence of a hard martensitic structure. The immersed AISI D2 specimens in $\mathrm{HCl}$ showed better corrosion resistance than that of AISI $\mathrm{O} 1$ due to the presence of high alloying elements, which may help in forming a protective layer against corrosion. The coarse-grained structures also showed better corrosion resistance, because of the small grain-boundary areas, which play a major role in initiating anodic sites for pit formation. Furthermore, the oxide precipitates of other alloying elements accumulate in grain-boundary areas, which could improve the corrosion behavior of the studied steels. 


\section{REFERENCES}

${ }^{1}$ W. Callister, D. Rethwisch, Materials Science and Engineering: an introduction, NewYork, Wiley, 2007, doi:10.1016/0025-5416(87) 90343-0

${ }^{2}$ N. Hansen, Hall-Petch relation and boundary strengthening, Scr. Mater., 51 (2004), 801-806, doi:10.1016/j.scriptamat.2004.06.002

${ }^{3}$ K. Ralston, N. Birbilis, Effect of grain size on corrosion: A review, Corrosion, 66 (2010), 075005-075005-13, doi:10.5006/1.3462912

${ }^{4}$ S. Krenk, Friction, dilation, and plastic flow potential, in: Physics of Dry Granular Media, Springer Netherlands, Dordrecht, (1998), 255-260, doi:10.1007/978-94-017-2653-5_17

${ }^{5}$ C. Obayi, R. Tolouei, A. Mostavan, C. Paternoster, S. Turgeon, A. Okorie, D. O. Oray, M. Diego, Effect of grain sizes on mechanical properties and biodegradation behavior of pure iron for cardiovascular stent application, Biomatter, 6 (2016), e959874, doi:10.4161/ 21592527.2014.959874

${ }^{6}$ G. Totten, L. Xie, K. Funatani, Handbook of Mechanical Alloy Design, Marcel Dekker Inc., New York, NY, 2004

${ }^{7}$ J. C. Díaz-Guillén, D. Guillén, G. Gutiérrez, González-Albarrán, México C P, Electrochemical corrosion performance of AISI D2 tool steel surface hardened by pulsed plasma nitriding, Int. J. Electrochem. Sci., 8 (2013), 973-982, www.electrochemsci.org

${ }^{8}$ K. O. Orubite, N. C. Ngobiri, Corn silk as corrosion inhibitor for mild steel in $0.1 \mathrm{M} \mathrm{HCl}$ medium, IOSR J. Appl. Chem., 10 (2017) 51-60, doi:10.9790/5736-1003015160

${ }^{9}$ C. Wei, F. Chen, Characterization on multi-layer fabricated by TRD and plasma nitriding, Mater. Chem. Phys., 90 (2005), 178-184, doi:10.1016/j.matchemphys.2004.10.008

${ }^{10}$ N. Yasavol, H. Jafari, Microstructure, mechanical and corrosion properties of friction stir-processed AISI D2 tool steel, J. Mater. Eng. Perform, 24 (2015), 2151-2157, doi:10.1007/s11665-015-1484-3

${ }^{11}$ ASTM E112-12, Standard Test Methods for Determining Average Grain Size, in: B. Stand., Volume: 3, ASTM International, West Conshohocken, PA, 2012

${ }^{12}$ ASTM International, ASTM G31-72, Standard Practice for Laboratory Immersion Corrosion Testing of Metals, 2004
${ }^{13}$ G. Roberts, G. Krauss, R. Kennedy, Tool Steels, 5th ed., ASM International, Materials Park, Ohio, USA 1998, 1

${ }^{14}$ H. Chandler, ed., Heat Treater's Guide: Practices and Procedures for Irons and Steels, 2nd ed., ASM International, Materials Park, Ohio, USA, 1995

${ }^{15}$ A. I. Zaid, A. O. Mostafa, Effect of hafnium addition on wear resistance of zinc-aluminum 5 alloy: A three-dimensional presentation, Adv. Mater. Lett.,8 (2017), 910-915, doi:10.5185/amlett.2017.1662

${ }^{16}$ A. O. Mostafa, Mechanical properties, and wear behavior of aluminum grain refined by Ti and Ti+B, Int. J. Surf. Eng. Interdiscip. Mater. Sci., 7 (2019), 1-19, doi:10.4018/IJSEIMS.2019010101

${ }^{17}$ J. Li, P. Zhao, J. Yanagimoto, S. Sugiyama, Y. Chen, Effects of heat treatment on the microstructures and mechanical properties of a new type of nitrogen-containing die steel, Int. J. Miner. Metall. Mater., 19 (2012), 511-517. doi:10.1007/s12613-012-0588-0

${ }^{18}$ Y. Zhang, J. Li, C.-B. Shi, Y.-F. Qi, Q.-T. Zhu, Effect of heat treatment on the microstructure and mechanical properties of nitrogen-alloyed high-Mn austenitic hot work die steel, Metals (Basel). 7 (2017), 94, doi:10.3390/met7030094

${ }^{19}$ M. A. Amin, K. F. Khaled, S. A. Fadl-Allah, Testing validity of the tafel extrapolation method for monitoring corrosion of cold rolled steel in $\mathrm{HCl}$ solutions - Experimental and theoretical studies, Corros. Sci., 52 (2010), 140-151, doi:10.1016/j.corsci.2009.08.055

${ }^{20} \mathrm{G}$. S. Frankel, Fundamentals of corrosion kinetics, in: Act. Prot. Coatings, (2016), 17-32. doi:10.1007/978-94-017-7540-3_2

${ }^{21}$ D. G. Enos, L. L. Scribner, The Potentiodynamic Polarization Scan, n.d. http://www.solartron.com (accessed August 12, 2019)

${ }^{22}$ M. S. El-Sayed, A. H. Seikh, Effects of Grain Refinement on the Corrosion Behaviour of Microalloyed Steel in Sulphuric Acid Solutions, Int. J. Electrochem. Sci. 7 (2012) 7567-7578

${ }^{23} \mathrm{~T}$. Remmerswaal, The influence of microstructure on the corrosion behavior of ferritic-martensitic steel, Delft University of Technology, 2015

${ }^{24}$ R. W. Revie, H. H. Uhlig, Corrosion and corrosion control: An introduction to corrosion Science and Engineering: Fourth Edition, 2008, doi: $10.1002 / 9780470277270$ 